ARTICLE

\title{
A chemically self-charging aqueous zinc-ion battery
}

Yan Zhang ${ }^{1}$, Fang Wan ${ }^{1}$, Shuo Huang ${ }^{1}$, Shuai Wang ${ }^{1}$, Zhiqiang Niu (iD ${ }^{1 凶} \&$ Jun Chen (iD ${ }^{1}$

Self-charging power systems integrating energy harvesting technologies and batteries are attracting extensive attention in energy technologies. However, the conventional integrated systems are highly dependent on the availability of the energy sources and generally possess complicated configuration. Herein, we develop chemically self-charging aqueous zinc-ion batteries with a simplified two-electrode configuration based on $\mathrm{CaV}_{6} \mathrm{O}_{16} \cdot 3 \mathrm{H}_{2} \mathrm{O}$ electrode. Such system possesses the capability of energy harvesting, conversion and storage simultaneously. It can be chemically self-recharged by the spontaneous redox reaction between the discharged cathode and oxygen from the ambient environment. Chemically selfrecharged zinc-ion batteries display an initial open-circuit voltage of about $1.05 \mathrm{~V}$ and a considerable discharge capacity of about $239 \mathrm{mAhg}^{-1}$, indicating the excellent selfrechargeability. Impressively, such chemically self-charging zinc-ion batteries can also work well at chemical or/and galvanostatic charging hybrid modes. This work not only provides a route to design chemically self-charging energy storage, but also broadens the horizons of aqueous zinc-ion batteries.

\footnotetext{
${ }^{1}$ Key Laboratory of Advanced Energy Materials Chemistry (Ministry of Education), Renewable Energy Conversion and Storage Center, College of Chemistry, Nankai University, Tianjin 300071, People's Republic of China. ${ }_{\text {email: }}$ zqniu@nankai.edu.cn
} 
$\mathrm{R}$ echargeable batteries are widely used in many fields, such as electric devices and grid-scale energy storage systems ${ }^{1-4}$. In general, the commercial batteries are often charged by electrical grid. However, in the harsh environment or remote area, the electrical grid is unavailable, which limits the recharging and reuse of batteries. In order to solve this issue, various energy harvesting technologies, such as photovoltaic devices ${ }^{5-11}$, piezoelectric nanogenerators ${ }^{12,13}$, triboelectric nanogenerators ${ }^{14,15}$, and thermoelectrics ${ }^{16-18}$, were integrated with batteries into selfcharging power systems. However, these systems are highly dependent on the energy resources, which are not always available in some environment or during a certain period of time. Furthermore, the configurations of these integrated systems are usually complicated and many extra components (e.g., photoelectrodes or temperature-sensitive redox couples) are required in comparison with the traditional batteries with two-electrode configuration. Therefore, self-charging power systems that possess simplified configuration and are available in various environments must be considered.

Chemical energy stored in molecules is an available energy source and can be converted into electrical energy through redox reaction $^{19-22}$. In this regard, chemical energy of oxygen that is an abundant resource in air is attracting much more attention in the energy conversion and storage devices, such as metal-air batteries. Furthermore, the metal-air batteries can be further integrated with other energy storage devices and charge them ${ }^{23,24}$. However, in such integrated devices, the metal-air components cannot always compensate the energy consumption of energy storage devices, and they have to be recharged by external power supply to recover when both the metal-air and energy storage components are exhausted ${ }^{23}$. Therefore, they cannot meet the demand in some case, where the batteries are required to be charged directly by the successive chemical energy conversion of oxygen on their cathodes. Recently, a variety of vanadium-based compounds have been developed to serve as the cathode materials of aqueous zinc-ion batteries (ZIBs) due to their open-framework crystal structure and multiple oxidation states of vanadium ${ }^{25-30}$. During the discharge process, the insertion of $\mathrm{Zn}^{2+}$ ions and reduction of vanadium occur simultaneously in vanadium-based ZIBs. Furthermore, it is noted that vanadium-based compounds are also active redox materials and can be oxidized by oxygen in low valence state. Therefore, the discharged vanadium-based cathodes would be oxidized by oxygen in the ambient environment, like a charge process. As a result, self-charging ZIBs that simultaneously possess energy conversion and storage functions would be achieved.

Inspired by this, we develop a chemically self-charging aqueous ZIBs system, in which the chemical energy harvesting, conversion, and storage are integrated in a single $\mathrm{CaV}_{6} \mathrm{O}_{16} \cdot 3 \mathrm{H}_{2} \mathrm{O}$ $(\mathrm{CaVO})$ cathode. Such system possesses a similar two-electrode configuration with the conventional ZIBs. It can harvest energy from ambient environment through spontaneous redox reaction, and then convert chemical energy into electrical energy and store them in ZIBs. Therefore, the resultant ZIBs can be self recharged by directly exposing $\mathrm{CaVO}$ cathodes to air without any external power supply. This design would provide a promising research direction for the next-generation self-powered systems.

\section{Results}

Preparation and characterization of CaVO nanoribbons. The $\mathrm{CaVO}$ nanoribbons were synthesized via a one-step hydrothermal $\operatorname{method}^{31}$. They display a size of several hundred micrometers in length and 200-500 $\mathrm{nm}$ in width (Fig. 1a, d). Their crystalline phase was further understood by X-ray diffraction (XRD) and the corresponding Rietveld refinement, as shown in Fig. 1b. The results show that the diffraction peaks can be well indexed to the monoclinic $\mathrm{CaVO}$ phase with space group of A2/m (JCPDS 33317) and lattice parameters of $a=12.2533 \AA, b=3.5149 \AA$, $c=18.3874 \AA, \alpha=\gamma=90.0^{\circ}$, and $\beta=118.642^{\circ}$. Thermogravimetric analysis (TGA) also confirms that three molecular waters exist in a formula unit (Supplementary Fig. 1, Supplementary Note 1). Furthermore, it is noted that the XRD pattern exhibits multiple (00l) reflections and the intensity of (002) reflection is extremely strong. It suggests that $\mathrm{CaVO}$ nanoribbons possess a typical layered structure, which is constructed by the stacking of $\mathrm{V}_{6} \mathrm{O}_{16}$ framework and the hydrated $\mathrm{Ca}$ atoms act as "pillars" between the $\mathrm{V}_{6} \mathrm{O}_{16}$ layers to stabilize the layered structure (Fig. 1c) $)^{32,33}$. In addition, the lattice fringes with $d$-spacing of $0.205 \mathrm{~nm}$ is observed in the high-resolution transmission electron microscopy (HRTEM) image, corresponding to the (008) plane of CaVO (Fig. 1e), which is in good agreement with the XRD result. Moreover, the transmission electron microscopy (TEM) elemental mapping images clearly show that $\mathrm{Ca}, \mathrm{V}$, and $\mathrm{O}$ element are homogeneously distributed in $\mathrm{CaVO}$ nanoribbons (Fig. 1f).

Electrochemical performance of $\mathrm{Zn} / \mathrm{CaVO}$ batteries. The favorable morphological features, open framework and expanded interlayer spacing $(0.819 \mathrm{~nm})$ would contribute to the fast kinetics of $\mathrm{Zn}^{2+}$ ions insertion/extraction in CaVO (refs. ${ }^{26,34-36}$ ), thereby enhancing their electrochemical performance. The electrochemical performance of $\mathrm{CaVO}$ nanoribbons was investigated in coin cells. In their cyclic voltammetry $(\mathrm{CV})$ curves, there are two pairs of reduction/oxidation peaks at $0.75 / 0.95$ and $0.47 / 0.66 \mathrm{~V}$ (Fig. 2a). They can be ascribed to a two-step redox reaction associated with $\mathrm{Zn}^{2+}$ ion insertion/extraction (corresponding analysis see the following energy storage mechanism section), corresponding to the valence change of vanadium from $\mathrm{V}^{5+}$ to $\mathrm{V}^{4+}$ and $\mathrm{V}^{4+}$ to $\mathrm{V}^{3+}$, respectively ${ }^{26,37,38}$. Furthermore, the CV curves display similar shape after first cycle, suggesting the high reversibility of the charge/discharge process of $\mathrm{Zn} / \mathrm{CaVO}$ batteries, which is further confirmed by the reversible galvanostatic charge/discharge (GCD) profiles (Fig. 2b). Besides, $\mathrm{Zn} / \mathrm{CaVO}$ batteries deliver a high initial discharge capacity of $300 \mathrm{~mA} \mathrm{~h} \mathrm{~g}^{-1}$ at $0.1 \mathrm{~A} \mathrm{~g}^{-1}$ and an average operating voltage of $\sim 0.7 \mathrm{~V}$ versus $\mathrm{Zn}^{2+} / \mathrm{Zn}$, corresponding to an insertion of $\sim 3.6 \mathrm{Zn}$ per unit formula of $\mathrm{CaVO}$. Impressively, even the current density is up to $30 \mathrm{Ag}^{-1}$, a capacity of $62 \mathrm{mAh} \mathrm{g}^{-1}$ is still achieved (Fig. 2c). When the current density recovers from 30 to $0.2 \mathrm{~A} \mathrm{~g}^{-1}$ after 70 cycles, the capacity is able to recover to the initial capacity of $\sim 290 \mathrm{mAh} \mathrm{g}^{-1}$. Such excellent rate capability of $\mathrm{Zn} / \mathrm{CaVO}$ batteries significantly depends on their electrochemical kinetics, as suggested by CV measurements at different scan rates (see Supplementary Fig. 2 and detailed calculation in Supplementary Note 2). The high surface-controlled capacity contributions result in the fast $\mathrm{Zn}^{2+}$ ion diffusion, enabling the high rate capability as well as outstanding cycling stability ${ }^{39-42}$. The capacity of $\mathrm{Zn} /$ CaVO batteries is still $263 \mathrm{mAh} \mathrm{g}^{-1}$ after 100 cycles at $0.5 \mathrm{~A} \mathrm{~g}^{-1}$ (Supplementary Fig. 3). Impressively, even after 10,000 cycles at a high current density of $10 \mathrm{~A} \mathrm{~g}^{-1}$, there is no degradation in their capacity, remaining stable at $\sim 170 \mathrm{~mA} \mathrm{~h} \mathrm{~g}^{-1}$ (Fig. 2d). During initial 200 cycles, the capacity is gradually increased, which is attributed to the activation of $\mathrm{CaVO}$ at a high current density of $10 \mathrm{Ag}^{-1}$ (refs. ${ }^{43,44}$ ).

Energy storage mechanism of $\mathrm{Zn} / \mathrm{CaVO}$ batteries. The fast reaction kinetics and excellent electrochemical performance depend on the energy storage mechanism of $\mathrm{Zn} / \mathrm{CaVO}$ batteries. To further understand the energy storage mechanism of $\mathrm{Zn} /$ $\mathrm{CaVO}$ system, various measurements, including in situ/ex situ XRD, ex situ TEM, X-ray photoelectron spectrometry (XPS) and 

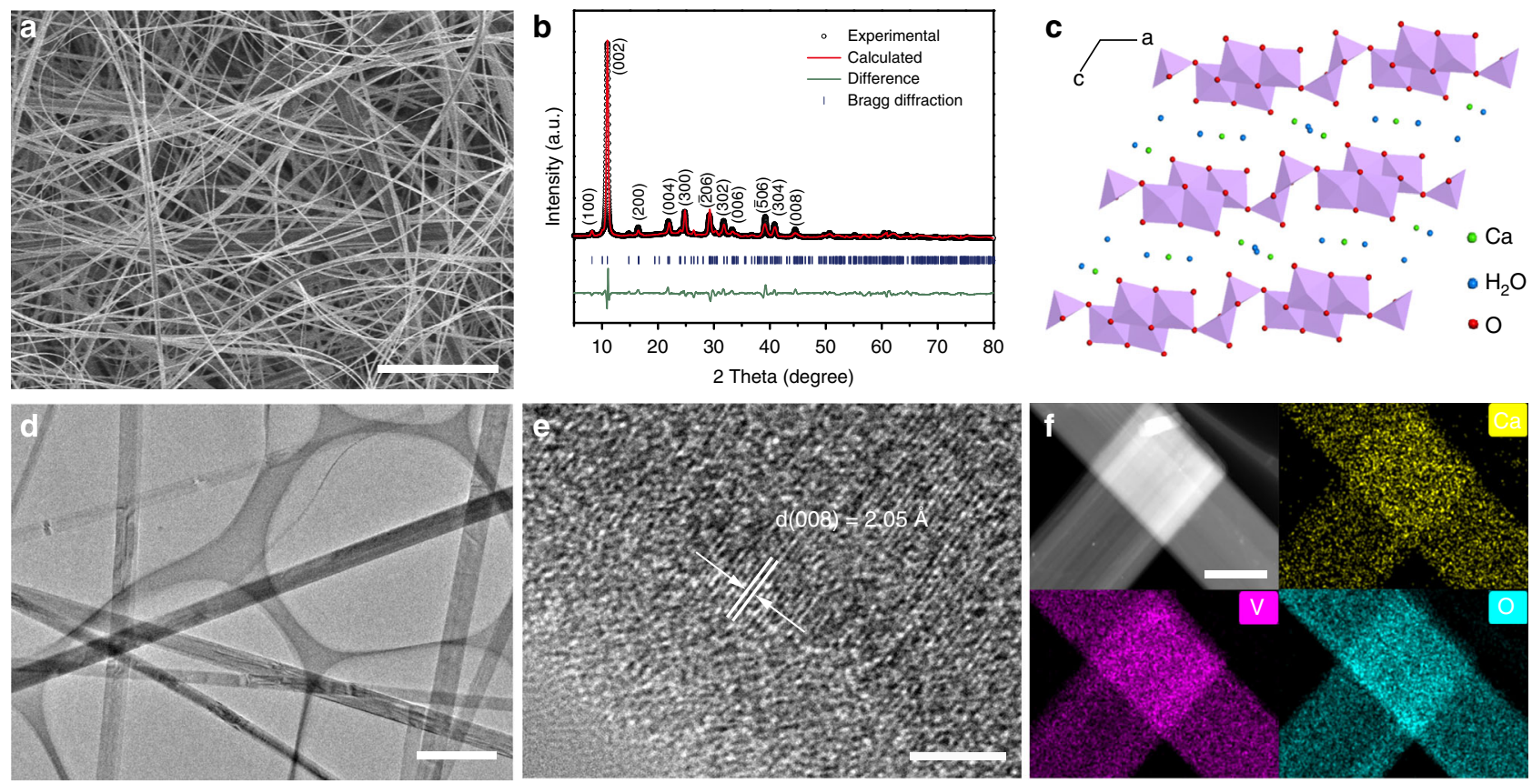

Fig. 1 Morphology and crystal structure of CaVO nanoribbons. a SEM image. b Rietveld refinement of the XRD pattern. c Crystal structure. $\mathbf{d}$ TEM image. e HRTEM image. f TEM elemental mapping images. Scale bars: a $10 \mu \mathrm{m} ; \mathbf{d} 1 \mu \mathrm{m}$; e $3 \mathrm{~nm}$; and $\mathbf{f} 400 \mathrm{~nm}$.

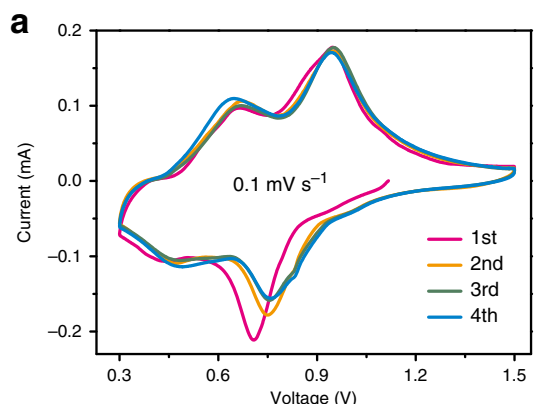

b
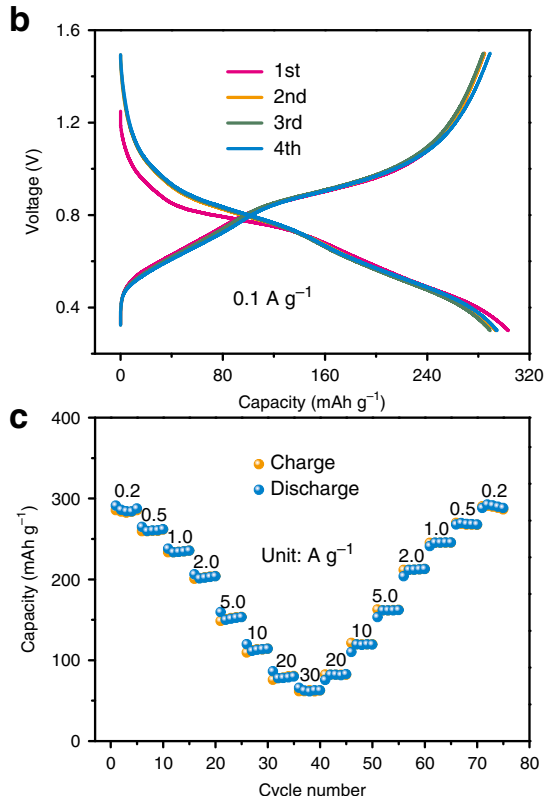



e
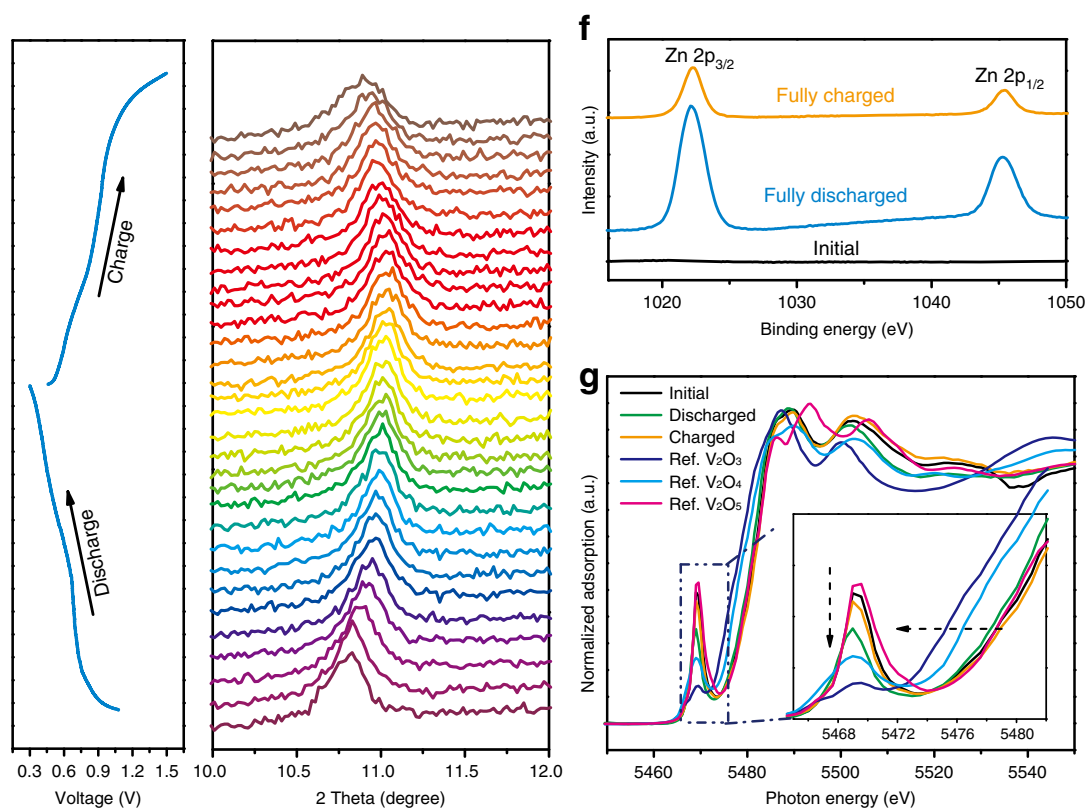

Fig. 2 Electrochemical performance and mechanism of $\mathbf{Z n} / \mathbf{C a V O}$ batteries. a CV curves at $0.1 \mathrm{mV} \mathrm{s}^{-1}$. b GCD curves at $0.1 \mathrm{Ag}^{-1}$. c Rate capability at various current densities. d Cycling performance at $10 \mathrm{~A} \mathrm{~g}^{-1}$. e In situ XRD patterns of (002) reflection and corresponding GCD curves at $0.2 \mathrm{~A} \mathrm{~g}{ }^{-1}$ during the first cycle. $\mathbf{f} X P S$ spectra of $\mathrm{Zn} 2 \mathrm{p}$ at initial, fully discharged, and charged states. $\mathbf{g} \vee$ K-edge XANES curves at initial, fully discharged, and charged states with reference to the standard $\mathrm{V}_{2} \mathrm{O}_{3}, \mathrm{VO}_{2}$, and $\mathrm{V}_{2} \mathrm{O}_{5}$. 
X-ray absorption near-edge spectroscopy (XANES) were utilized to characterize the $\mathrm{CaVO}$ cathodes at the selected states of charge/ discharge process. It is noted that the XRD characteristic diffraction peaks of (002) and (004) plane shift slightly toward high degree during the discharge process, corresponding to the decrease of interlayer spacing (Fig. 2e, Supplementary Figs. 4 and 5). It is ascribed to the strong electrostatic interaction between intercalated $\mathrm{Zn}^{2+}$ ions and $\mathrm{V}_{6} \mathrm{O}_{16}$ layers ${ }^{38,45}$. In contrast, the (206) reflection shifts slightly toward low degree, corresponding to the expansion of the interlayer spacing of (206) plane, which could arise from the reduction of $\mathrm{V}^{5+} / \mathrm{V}^{4+}$ upon $\mathrm{Zn}^{2+}$ ion insertion and the resultant increase in the $\mathrm{V}-\mathrm{V}$ bond distance between the layers ${ }^{43}$. Furthermore, the disorder in structure caused by $\mathrm{Zn}^{2+}$ ion insertion would result in the broadening of (206) and (006) reflections. Reversibly, during the subsequent charge process, these characteristic diffraction peaks gradually return to their original state with the extraction of $\mathrm{Zn}^{2+}$ ions. This reversible change of interlayer spacing is also confirmed by the HRTEM images (Supplementary Fig. 6). Therefore, the energy storage mechanism of $\mathrm{Zn} / \mathrm{CaVO}$ batteries is the insertion/ extraction of $\mathrm{Zn}^{2+}$ ions into/from the CaVO (Supplementary Fig. 7, Supplementary Note 3), which is similar to the case of conventional ZIBs (refs. ${ }^{30,46}$ ). Moreover, this $\mathrm{Zn}^{2+}$ ion insertion/ extraction mechanism is further substantiated by the XPS analysis of $\mathrm{Zn} 2 \mathrm{p}$ peaks (Fig. 2f). The peaks of $\mathrm{Zn} 2 \mathrm{p}$ are not detected in the initial $\mathrm{CaVO}$ cathode, whereas strong peaks are observed at the fully discharged state, corresponding to the intercalated $\mathrm{Zn}^{2+}$ ions. In contrast, at the fully charged state, the intensity of $\mathrm{Zn} 2 \mathrm{p}$ peaks is significantly weakened, suggesting that most of $\mathrm{Zn}^{2+}$ ions are extracted from the CaVO. It is also proved by TEM elemental mapping images, where $\mathrm{Zn}$ element is uniformly distributed in the nanoribbons at fully discharged state and then almost disappears at fully charged state (Supplementary Fig. 8). The insertion/extraction of $\mathrm{Zn}^{2+}$ ions is accompanied by the valence change of vanadium in CaVO, as illustrated in $\mathrm{V}$ K-edge XANES curves of CaVO cathodes at different charge/discharge states (Fig. 2g). Compared with the initial state, the main absorption edge slightly shifts toward lower binding energy at fully discharged state, suggesting that the average oxidation state of vanadium is reduced due to the insertion of $\mathrm{Zn}^{2+}$ ions ${ }^{47-49}$. Subsequently, the position of absorption edge reversibly shifts back toward higher energy at fully charged state, indicating the oxidation of vanadium caused by the extraction of $\mathrm{Zn}^{2+}$ ions from CaVO. The above insertion/extraction of $\mathrm{Zn}^{2+}$ ions during the charge/discharge process can also be reflected by the reversible intensity change of pre-edge peak in XANES (Fig. 2g), which is sensitive to the change of the local symmetry of $\mathrm{V}$ atoms ${ }^{50}$.

Based on the above results and discussion, the overall electrochemical reaction of the $\mathrm{Zn} / \mathrm{CaVO}$ batteries can be described as follows:

Cathode:

$$
\mathrm{CaV}_{6} \mathrm{O}_{16} \cdot 3 \mathrm{H}_{2} \mathrm{O}+3.6 \mathrm{Zn}^{2+}+7.2 e^{-} \leftrightarrow \mathrm{CaZn}_{3.6} \mathrm{~V}_{6} \mathrm{O}_{16} \cdot 3 \mathrm{H}_{2} \mathrm{O}
$$

Anode:

$$
3.6 \mathrm{Zn} \leftrightarrow 3.6 \mathrm{Zn}^{2+}+7.2 e^{-}
$$

Overall:

$$
\mathrm{CaV}_{6} \mathrm{O}_{16} \cdot 3 \mathrm{H}_{2} \mathrm{O}+3.6 \mathrm{Zn} \leftrightarrow \mathrm{CaZn}_{3.6} \mathrm{~V}_{6} \mathrm{O}_{16} \cdot 3 \mathrm{H}_{2} \mathrm{O}
$$

Chemically self-charging mechanism. The CaVO cathodes exhibit excellent $\mathrm{Zn}^{2+}$ ion storage performance, and the reduction/oxidation of vanadium occurs during the $\mathrm{Zn}^{2+}$ ion insertion/ extraction. In the galvanostatic charging process, electrons are released from the $\mathrm{CaZn}_{3.6} \mathrm{~V}_{6} \mathrm{O}_{16} \cdot 3 \mathrm{H}_{2} \mathrm{O}\left(\mathrm{CaZn}_{3.6} \mathrm{VO}\right)$ cathode. As a result, vanadium in $\mathrm{CaZn}_{3.6} \mathrm{VO}$ is oxidized and the $\mathrm{Zn}^{2+}$ ions are extracted from the layered structure simultaneously. In this process, the driving force of the release of electron from $\mathrm{CaZn}_{3.6} \mathrm{VO}$ is generally the external power supply. In addition to above-mentioned electrochemical oxidation reaction, other strategies that can realize the electron transfer from $\mathrm{CaZn}_{3.6} \mathrm{VO}$ would be also promising to carry out the charging process of the ZIBs based on $\mathrm{CaZn}_{3.6} \mathrm{VO}$ cathode. It is well known that redox reaction is an effective and straightforward approach to realize the electron transfer, which is driven by the redox potential difference $(\Delta E)$ between reactants ${ }^{51,52}$. In the case of $\mathrm{CaZn}_{3.6} \mathrm{VO}$, the redox potential in this system can be obtained from the $\mathrm{CV}$ curves of $\mathrm{Zn} / \mathrm{CaVO}$ batteries (Fig. $2 \mathrm{a})^{53}$, in which the minimum reduction peak potential of $\mathrm{CaVO}$ versus $\mathrm{Zn}^{2+} / \mathrm{Zn}$ is $0.47 \mathrm{~V}$. According to the Nernst equation, the calculated redox potential of $\mathrm{CaZn}_{3.6} \mathrm{VO}$ is $-0.27 \mathrm{~V}$ versus standard hydrogen electrode (SHE). Theoretically, CaZn ${ }_{3.6} \mathrm{VO}$ can be oxidized spontaneously by the oxidants with a higher potential than $-0.27 \mathrm{~V}$ versus SHE. Among various oxidants, $\mathrm{O}_{2}$ is common and abundant in the air, the standard electrode potentials $\left(E^{\theta}\right)$ of which are $\sim 0.40 \mathrm{~V}$ and $\sim 1.23 \mathrm{~V}$ versus SHE in the neutral and acidic medium, respectively. Owing to the difference in redox potential between $\mathrm{O}_{2}$ and $\mathrm{CaZn}_{3.6} \mathrm{VO}$, the $\mathrm{CaZn}_{3.6} \mathrm{VO}$ tends to release electrons to be oxidized and $\mathrm{O}_{2}$ can accept these electrons to be reduced simultaneously (Fig. 3a). Therefore, if the redox reaction between $\mathrm{CaZn}_{3.6} \mathrm{VO}$ and $\mathrm{O}_{2}$ could take place, the oxidation of vanadium in $\mathrm{CaZn}_{3.6} \mathrm{VO}$ would be realized, and the $\mathrm{Zn}^{2+}$ ions would be extracted from the layered structure to balance the charge at the same time. As a result, the fully discharged product $\mathrm{CaZn}_{3.6} \mathrm{VO}$ would recover to its charged states $\mathrm{CaZn}_{3.6-\mathrm{x}} \mathrm{V}_{6} \mathrm{O}_{16} \cdot 3 \mathrm{H}_{2} \mathrm{O}$ $\left(\mathrm{CaZn}_{3.6-\mathrm{x}} \mathrm{VO}\right)$ without any external power supply. In the $\mathrm{Zn} /$ $\mathrm{CaVO}$ batteries, acidic $4 \mathrm{M} \mathrm{Zn}\left(\mathrm{CF}_{3} \mathrm{SO}_{3}\right)_{2}$ electrolyte was used. In an open device, $\mathrm{O}_{2}$ could be dissolved into such electrolyte and imported to the discharged product $\mathrm{CaZn}_{3.6} \mathrm{VO}$, realizing the redox reaction between $\mathrm{CaZn}_{3.6} \mathrm{VO}$ and $\mathrm{O}_{2}$. In order to validate the spontaneity of the redox reactions between $\mathrm{CaZn}_{3.6} \mathrm{VO}$ and $\mathrm{O}_{2}$ in the acidic $4 \mathrm{M} \mathrm{Zn}\left(\mathrm{CF}_{3} \mathrm{SO}_{3}\right)_{2}$ electrolyte, we designed a galvanic cell ${ }^{54,55}$

$$
(-) \mathrm{CaZn}_{3.6} \mathrm{VO}\left|\mathrm{CaZn}_{3.6-\mathrm{x}} \mathrm{VO}\right|\left|\mathrm{H}_{2} \mathrm{O}\right| \mathrm{O}_{2} \mid \mathrm{Pt}(+)
$$

As shown in Fig. $3 \mathrm{~b}$, the $\mathrm{CaZn}_{3.6} \mathrm{VO}$ electrode served as anode, which was in $4 \mathrm{M} \mathrm{Zn}\left(\mathrm{CF}_{3} \mathrm{SO}_{3}\right)_{2}$ electrolyte without the dissolved oxygen and sealed under Ar. The platinum wire was used as cathode, which was immersed in $4 \mathrm{M} \mathrm{Zn}\left(\mathrm{CF}_{3} \mathrm{SO}_{3}\right)_{2}$ solution containing dissolved oxygen. In this system, a cell voltage of $0.38 \mathrm{~V}$ was observed. According to the relationship between thermodynamic function and cell voltage:

$$
\Delta G=-n E F
$$

where, $\Delta G, F$, and $E$ are the free energy change, Faraday constant, and cell voltage, respectively, the free energy change is less than zero in this case, suggesting that the redox reaction between $\mathrm{CaZn}_{3.6} \mathrm{VO}$ and $\mathrm{O}_{2}$ can take place spontaneously in $4 \mathrm{M}$ zinc trifluoromethanesulfonate $\left(\mathrm{Zn}\left(\mathrm{CF}_{3} \mathrm{SO}_{3}\right)_{2}\right)$ solution at ambient condition.

To gain insight into the process of such redox reaction, various ex situ characterizations were carried out to investigate the structure and composition evolution of $\mathrm{CaZn}_{3.6} \mathrm{VO}$ electrodes that were immersed in $4 \mathrm{M} \mathrm{Zn}\left(\mathrm{CF}_{3} \mathrm{SO}_{3}\right)_{2}$ to react with the dissolved oxygen for different times. With the extension of immersion time from 0 (fully discharged state) to $36 \mathrm{~h}$, the V $2 \mathrm{p}$ peak in the XPS spectra gradually shifts toward higher binding energy (Fig. 3c), where the intensity of $\mathrm{V}^{5+}$ peak is significantly enhanced and $\mathrm{V}^{3+}$ peak disappears in comparison with those of 


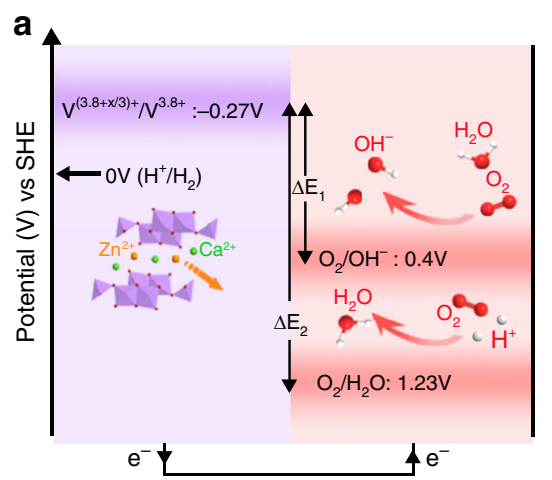

b

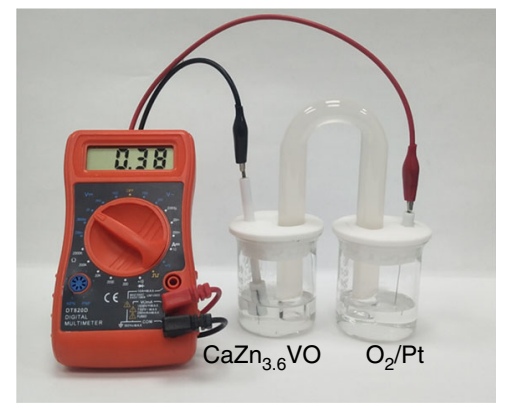

c

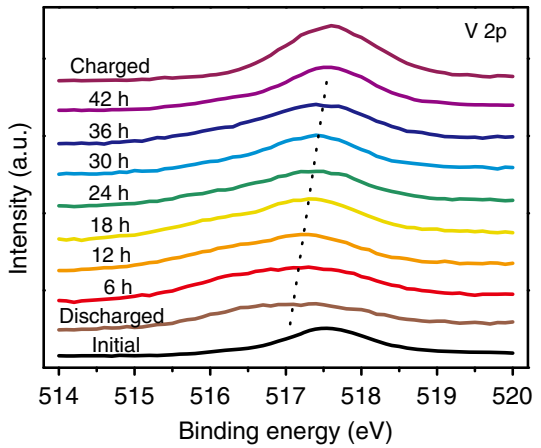

f

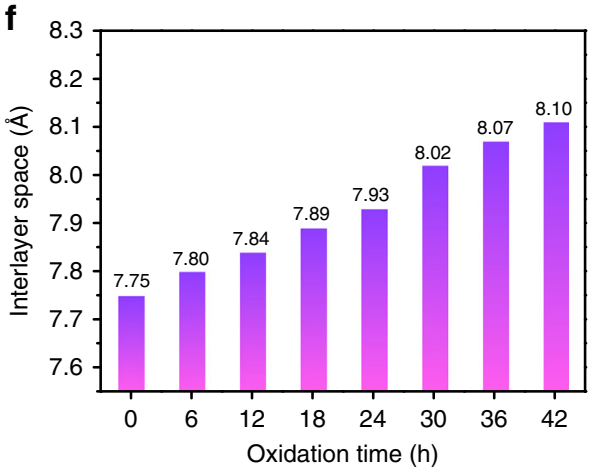

Fig. 3 The mechanism of the redox reaction between $\mathbf{C a Z n}_{\mathbf{3 . 6}} \mathbf{V O}$ and $\mathbf{O}_{\mathbf{2}}$. a Energy level transition diagram of $\mathrm{CaZn} \mathrm{n}_{3.6} \mathrm{VO}$ and $\mathrm{O}_{2}$. $\mathbf{b}$ Optical image of the designed galvanic cell. $\mathbf{c} \vee 2 \mathrm{p}$ XPS spectra of the $\mathrm{CaVO}$ electrodes at different states and the $\mathrm{CaZn}_{3.6} \vee \mathrm{O}$ electrodes after being oxidized by $\mathrm{O}_{2}$ in $4 \mathrm{M} \mathrm{Zn}$ $\left(\mathrm{CF}_{3} \mathrm{SO}_{3}\right)_{2}$ solution for different times. $\mathbf{d}$ Comparison of XPS spectra of $\mathrm{V} 2 \mathrm{p}$ before and after oxidation. e XRD patterns and $\mathbf{f}$ calculational interlayer spacing of (002) plane of $\mathrm{CaZn}_{3.6} \mathrm{VO}$ electrodes after being oxidized by $\mathrm{O}_{2}$ for different times.

initial $\mathrm{CaZn}_{3.6} \mathrm{VO}$ (Fig. $3 \mathrm{~d}$ ), suggesting the oxidation of vanadium in $\mathrm{CaZn}_{3.6} \mathrm{VO}$ during the redox reaction process. Simultaneously, to balance the charge of $\mathrm{CaZn}_{3.6} \mathrm{VO}$, the intercalated $\mathrm{Zn}^{2+}$ ions are extracted from the layered structure, resulting in the increase of the interlayer spacing of $\mathrm{CaZn}_{3.6} \mathrm{VO}$, as proved by the XRD pattern. Furthermore, it is worth noting that the amount of extracted $\mathrm{Zn}^{2+}$ ions of $\mathrm{CaZn}_{3.6} \mathrm{VO}$ can be effectively controlled by varying the oxidation time in this system. The (002) reflection of oxidized $\mathrm{CaZn}_{3.6} \mathrm{VO}$ gradually shifts toward lower degree with the extension of oxidation time (Fig. 3e, Supplementary Figs. 5 and 9, Supplementary Note 4$)$. According to the Bragg equation ( $2 d \sin \theta$ $=n \lambda, n=1, \lambda=0.154 \mathrm{~nm})$, the interlayer spacing of (002) plane is calculated and increases from 7.75 to $8.10 \AA$ after oxidation for $42 \mathrm{~h}$ (Fig. 3f). In addition, it is noted that V 2p XPS spectra and the (002) reflection will not further shifts when the oxidation time exceeds $36 \mathrm{~h}$ (Fig. 3c, e), suggesting the oxidation of vanadium in $\mathrm{CaZn}_{3.6} \mathrm{VO}$ and the extraction of $\mathrm{Zn}^{2+}$ ions would be finished within $36 \mathrm{~h}$.

In addition to $\mathrm{O}_{2}$, it is noted that $\mathrm{H}_{2} \mathrm{O}$ also plays an important role in the redox reaction process. In order to demonstrate this, the $\mathrm{CaZn}_{3.6} \mathrm{VO}$ electrodes were immersed in acetonitrile containing dissolved oxygen. In the absence of $\mathrm{H}_{2} \mathrm{O}$, the oxidation of vanadium is not detected in the resultant $\mathrm{CaZn}_{3.6} \mathrm{VO}$, as reflected by the V 2 p XPS spectra, where $\mathrm{V} 2 \mathrm{p}$ region remains unchanged in comparison with that of the initial $\mathrm{CaZn}_{3.6} \mathrm{VO}$ (Supplementary Fig. 10). Furthermore, there is no shift in the XRD characteristic peak of the resultant $\mathrm{CaZn}_{3.6} \mathrm{VO}$ (Supplementary Fig. 11), indicating that the $\mathrm{Zn}^{2+}$ ions are not extracted from the $\mathrm{CaZn}_{3.6}$ VO. Clearly, the redox reaction between $\mathrm{CaZn}_{3.6} \mathrm{VO}$ and $\mathrm{O}_{2}$ cannot take place in the absence of $\mathrm{H}_{2} \mathrm{O}$. In case of the neutral aqueous solution, the redox reaction between $\mathrm{CaZn}_{3.6} \mathrm{VO}$ and $\mathrm{O}_{2}$ can also occur (Supplementary Figs. 12-16, Supplementary Notes 5 and 6), where $\mathrm{O}_{2}$ accepts the electrons from
$\mathrm{CaZn}_{3.6} \mathrm{VO}$ and reacts with $\mathrm{H}_{2} \mathrm{O}$ to form $\mathrm{OH}^{-}$. The generated $\mathrm{OH}^{-}$and extracted $\mathrm{Zn}^{2+}$ ions combine with the adsorbed electrolyte ions $\left(\mathrm{Zn}^{2+}\right.$ and $\left.\mathrm{CF}_{3} \mathrm{SO}_{3}{ }^{-}\right)$to form amorphous triflate containing layered double hydroxide $\mathrm{Zn}_{\mathrm{x}+\mathrm{y}}\left(\mathrm{CF}_{3} \mathrm{SO}_{3}\right)_{2 \mathrm{y}}(\mathrm{OH})_{2 \times}$ (see Supplementary Figs. 17-22 and discussion in Supplementary Notes $7-10)^{37,44,56,57}$. Based on the above discussion, in the neutral deionized water, the redox reaction between $\mathrm{CaZn}_{3.6} \mathrm{VO}$ and $\mathrm{O}_{2}$ can be summarized as below:

$$
\begin{gathered}
\mathrm{CaZn}_{3.6} \mathrm{~V}_{6} \mathrm{O}_{16} \cdot 3 \mathrm{H}_{2} \mathrm{O}+x / 2 \mathrm{O}_{2}+x \mathrm{H}_{2} \mathrm{O}+y \mathrm{Zn}\left(\mathrm{CF}_{3} \mathrm{SO}_{3}\right)_{2} \rightarrow \\
\mathrm{CaZn}_{3.6-\mathrm{x}} \mathrm{V}_{6} \mathrm{O}_{16} \cdot 3 \mathrm{H}_{2} \mathrm{O}+\mathrm{Zn}_{\mathrm{x}+\mathrm{y}}\left(\mathrm{CF}_{3} \mathrm{SO}_{3}\right)_{2 \mathrm{y}}(\mathrm{OH})_{2 \mathrm{x}}
\end{gathered}
$$

Different from the case in neutral deionized water, in the acidic $4 \mathrm{M} \mathrm{Zn}\left(\mathrm{CF}_{3} \mathrm{SO}_{3}\right)_{2}$ electrolyte, $\mathrm{O}_{2}$ is reduced to $\mathrm{H}_{2} \mathrm{O}$ in the presence of $\mathrm{H}^{+}$ions, and the $\mathrm{CaZn}_{3.6} \mathrm{VO}$ is oxidized along with the extraction of $\mathrm{Zn}^{2+}$ ions. The redox reaction mechanism can be expressed by the following half-cell reactions:

$$
\begin{aligned}
\mathrm{CaZn}_{3.6} \mathrm{~V}_{6} \mathrm{O}_{16} \cdot 3 \mathrm{H}_{2} \mathrm{O} \rightarrow \mathrm{CaZn}_{3.6-\mathrm{x}} & \mathrm{V}_{6} \mathrm{O}_{16} \cdot 3 \mathrm{H}_{2} \mathrm{O} \\
& +x \mathrm{Zn}^{2+}+2 x e^{-} \\
x / 2 \mathrm{O}_{2}+2 x \mathrm{H}^{+}+2 x e^{-} \rightarrow & x \mathrm{H}_{2} \mathrm{O}
\end{aligned}
$$

The continuous consumption of $\mathrm{H}^{+}$ions promotes the water dissociation, thus producing additional $\mathrm{H}^{+}$ions and $\mathrm{OH}^{-}$ions:

$$
2 x \mathrm{H}_{2} \mathrm{O} \rightarrow 2 x \mathrm{H}^{+}+2 x \mathrm{OH}^{-}
$$

The additional $\mathrm{H}^{+}$ions also participate in the oxygen reduction reaction $\left(\mathrm{O}_{2}+4 \mathrm{H}^{+}+4 \mathrm{e}^{-} \rightarrow 2 \mathrm{H}_{2} \mathrm{O}\right)$. The generated $\mathrm{OH}^{-}$ions react with electrolyte ions $\left(\mathrm{Zn}^{2+}\right.$ and $\left.\mathrm{CF}_{3} \mathrm{SO}_{3}{ }^{-}\right)$and $\mathrm{Zn}^{2+}$ ions that are extracted from the oxidation reaction of $\mathrm{CaZn}_{3.6} \mathrm{VO}$ to form $\mathrm{Zn}_{\mathrm{x}+\mathrm{y}}\left(\mathrm{CF}_{3} \mathrm{SO}_{3}\right)_{2 \mathrm{y}}(\mathrm{OH})_{2 \mathrm{x}}$ on the surface of 
a
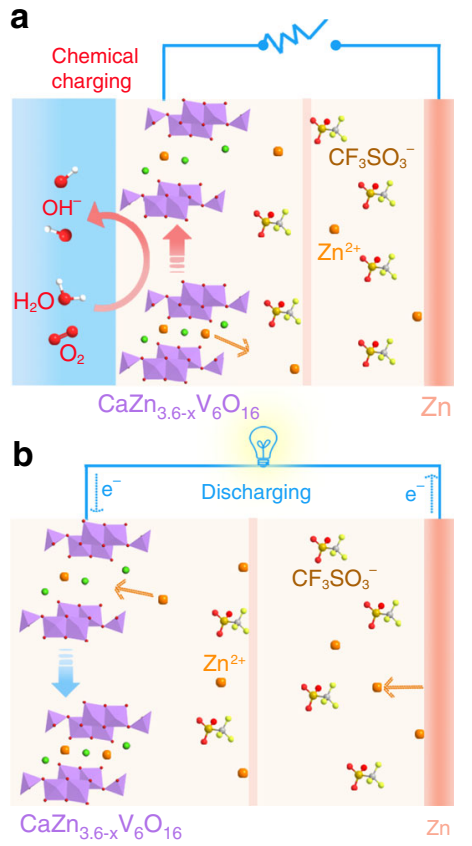

c
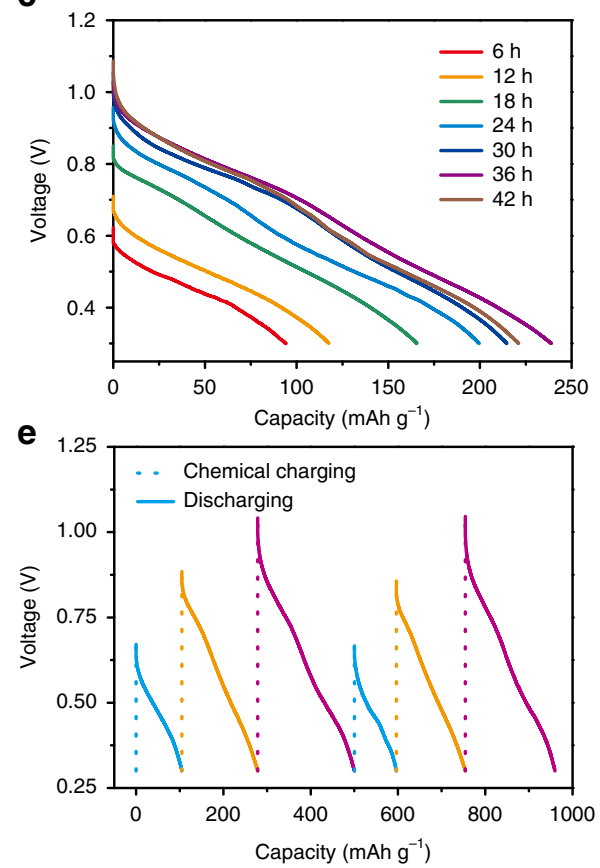

d


Fig. 4 Chemical charging/galvanostatic discharging behavior of $\mathbf{Z n} / \mathbf{C a Z n}_{\mathbf{3 . 6 - \mathbf { x }}} \mathbf{V O}$ batteries. Working mechanism of chemically self-charging ZIBs during a chemical charging and $\mathbf{b}$ galvanostatic discharging process. $\mathbf{c}$ The galvanostatic discharge curves of $\mathrm{Zn} / \mathrm{CaZn}_{3.6-x} \mathrm{VO}$ batteries at $0.1 \mathrm{Ag}^{-1}$ after the $\mathrm{CaZn}_{3.6} \mathrm{VO}$ electrodes were oxidized for different times. $\mathbf{d}$ Effect of the oxidation time on OCV and discharge capacity of $\mathrm{Zn} / \mathrm{CaZn} \mathrm{n}_{3.6-x} \mathrm{VO}$ batteries. e Voltage-time curves of the $\mathrm{Zn} / \mathrm{CaZn}_{3.6-x} \mathrm{VO}$ batteries after being chemically charged to different states (dotted lines: chemical charging for different times. Solid lines: galvanostatic discharging at $0.1 \mathrm{~A} \mathrm{~g}^{-1}$ ). $\mathbf{f}$ Chemical charging/galvanostatic discharging cycling stability of the $\mathrm{Zn}_{\mathrm{C}} \mathrm{CaZn} \mathrm{n}_{3.6-\mathrm{x}} \mathrm{VO}$ battery in a voltage window from 0.3 to $\sim 1.05 \mathrm{~V}$.

electrode (Supplementary Figs. 23 and 24):

$x \mathrm{Zn}^{2+}+y \mathrm{Zn}\left(\mathrm{CF}_{3} \mathrm{SO}_{3}\right)_{2}+2 x \mathrm{OH}^{-} \rightarrow \mathrm{Zn}_{\mathrm{x}+\mathrm{y}}\left(\mathrm{CF}_{3} \mathrm{SO}_{3}\right)_{2 \mathrm{y}}(\mathrm{OH})_{2 \mathrm{x}}$

The overall reaction can be expressed as:

$$
\begin{gathered}
\mathrm{CaZn}_{3.6} \mathrm{~V}_{6} \mathrm{O}_{16} \cdot 3 \mathrm{H}_{2} \mathrm{O}+x / 2 \mathrm{O}_{2}+x \mathrm{H}_{2} \mathrm{O}+y \mathrm{Zn}\left(\mathrm{CF}_{3} \mathrm{SO}_{3}\right)_{2} \rightarrow \\
\mathrm{CaZn}_{3.6-\mathrm{x}} \mathrm{V}_{6} \mathrm{O}_{16} \cdot 3 \mathrm{H}_{2} \mathrm{O}+\mathrm{Zn}_{\mathrm{x}+\mathrm{y}}\left(\mathrm{CF}_{3} \mathrm{SO}_{3}\right)_{2 \mathrm{y}}(\mathrm{OH})_{2 \mathrm{x}}
\end{gathered}
$$

Self-charging performance of ZIBs. The oxidation of vanadium and extraction of $\mathrm{Zn}^{2+}$ ions in $\mathrm{CaZn}_{3.6} \mathrm{VO}$ can spontaneously occur in the $4 \mathrm{M} \mathrm{Zn}\left(\mathrm{CF}_{3} \mathrm{SO}_{3}\right)_{2}$ electrolyte containing dissolved oxygen. Consequently, the fully discharged product $\mathrm{CaZn}_{3.6} \mathrm{VO}$ can recover to its charged states $\mathrm{CaZn}_{3.6-\mathrm{x}} \mathrm{VO}$ through spontaneous redox reaction, which could be considered as a chemical self-charging process (Fig. 4a). When the oxidized product $\mathrm{CaZn}_{3.6-\mathrm{x}} \mathrm{VO}$ electrode directly act as the cathode of ZIBs, the discharge process will take place due to the $\mathrm{Zn}^{2+}$ ion chemical potential difference between $\mathrm{CaZn}_{3.6-\mathrm{x}} \mathrm{VO}$ cathode and $\mathrm{Zn}$ anode, where anodic $\mathrm{Zn}$ is dissolved to form $\mathrm{Zn}^{2+}$ ions and then intercalate into the $\mathrm{CaZn}_{3.6-\mathrm{x}} \mathrm{VO}$ cathode (Fig. $\left.4 \mathrm{~b}\right)^{51}$. Simultaneously, electrons flow out of the anode to cathode through the external circuit to maintain electrical neutrality. In order to investigate the electrochemical performance of aqueous ZIBs based on $\mathrm{CaZn}_{3.6-\mathrm{x}} \mathrm{VO}$ cathodes, their galvanostatic discharge curves were measured. The open-circuit voltage (OCV) of the $\mathrm{Zn}$ / $\mathrm{CaZn}_{3.6-\mathrm{x}} \mathrm{VO}$ batteries rises continually along with extending the oxidation time of $\mathrm{CaZn}_{3.6} \mathrm{VO}$ (Fig. 4c, d). It is ascribed to the enhanced electrode potential of $\mathrm{CaZn}_{3.6-\mathrm{x}} \mathrm{VO}$ cathode as a result of the deeper oxidation of vanadium and the extraction of more $\mathrm{Zn}^{2+}$ ions, with the extension of oxidation time. When the $\mathrm{CaZn}_{3.6} \mathrm{VO}$ is oxidized for 36 and $42 \mathrm{~h}$, the OCV of $\mathrm{Zn} /$ $\mathrm{CaZn}_{3.6-\mathrm{x}} \mathrm{VO}$ batteries reaches up to 1.05 and $1.08 \mathrm{~V}$, respectively, which nearly reach to the initial OCV $(\sim 1.2 \mathrm{~V})$ of the $\mathrm{Zn} /$ $\mathrm{CaVO}$ battery. In addition to OCV, the discharge capacity of $\mathrm{Zn} / \mathrm{CaZn}_{3.6-\mathrm{x}} \mathrm{VO}$ batteries also depends on the oxidation time of $\mathrm{CaZn}_{3.6} \mathrm{VO}$. When the oxidation time is $<36 \mathrm{~h}$, the discharge capacity gradually increases with the prolongation of oxidation time and a discharge capacity of $239 \mathrm{mAh} \mathrm{g}^{-1}$ is achieved at $36 \mathrm{~h}$. It is much higher than the case of chemical charging in neutral deionized water (Supplementary Figs. 25 and 26, Supplementary Note 11). However, it is noted that the discharge capacity of $\mathrm{Zn} /$ $\mathrm{CaZn}_{3.6-\mathrm{x}} \mathrm{VO}$ batteries degrades when the oxidation time exceeds $36 \mathrm{~h}$, since the increasing $\mathrm{Zn}_{\mathrm{x}+\mathrm{y}}\left(\mathrm{CF}_{3} \mathrm{SO}_{3}\right)_{2 \mathrm{y}}(\mathrm{OH})_{2 \mathrm{x}}$ would hinder the subsequent insertion of $\mathrm{Zn}^{2+}$ ions. In addition, $\mathrm{Zn}$ / $\mathrm{CaZn} \mathrm{n}_{3.6-\mathrm{x}} \mathrm{VO}$ batteries display high reversibility of such chemical charging/galvanostatic discharging process even at different chemically self-charged states. When the chemical charging time is extended stepwise from 6 to $30 \mathrm{~h}$ and then abruptly switched back to $6 \mathrm{~h}$, the corresponding discharge capacity increases from 105.1 to $221.4 \mathrm{mAh} \mathrm{g}^{-1}$ and then returns to $96.4 \mathrm{mAh} \mathrm{g}^{-1}$ (Fig. $4 \mathrm{e}$ ). During the repeated chemical charging/galvanostatic discharging cycles, $\mathrm{CaZn}_{3.6-\mathrm{x}} \mathrm{VO}$ can be reversibly converted with $\mathrm{CaZn}{ }_{3.6} \mathrm{VO}$ (Supplementary Fig. 5). Different from $\mathrm{CaZn}_{3.6-\mathrm{x}} \mathrm{VO}$, the $\mathrm{Zn}_{\mathrm{x}+\mathrm{y}}\left(\mathrm{CF}_{3} \mathrm{SO}_{3}\right)_{2 \mathrm{y}}(\mathrm{OH})_{2 \mathrm{x}}$ is progressively generated and aggregated on the electrode, which will inevitably increase electrochemical impedance and hinder the insertion of $\mathrm{Zn}^{2+}$ ions during subsequent cycles, resulting in the capacity degradation (Fig. 4f). Importantly, after the electrochemical charging process, most $\mathrm{Zn}_{\mathrm{x}+\mathrm{y}}\left(\mathrm{CF}_{3} \mathrm{SO}_{3}\right)_{2 \mathrm{y}}(\mathrm{OH})_{2 \mathrm{x}}$ would be decomposed and disappear from the electrode (Supplementary Fig. 27, Supplementary Note 12). Therefore, the chemical-charging ability and capacity will recover to a large extent after the electrochemical charging process. However, it is noted that there is still a capacity decay 

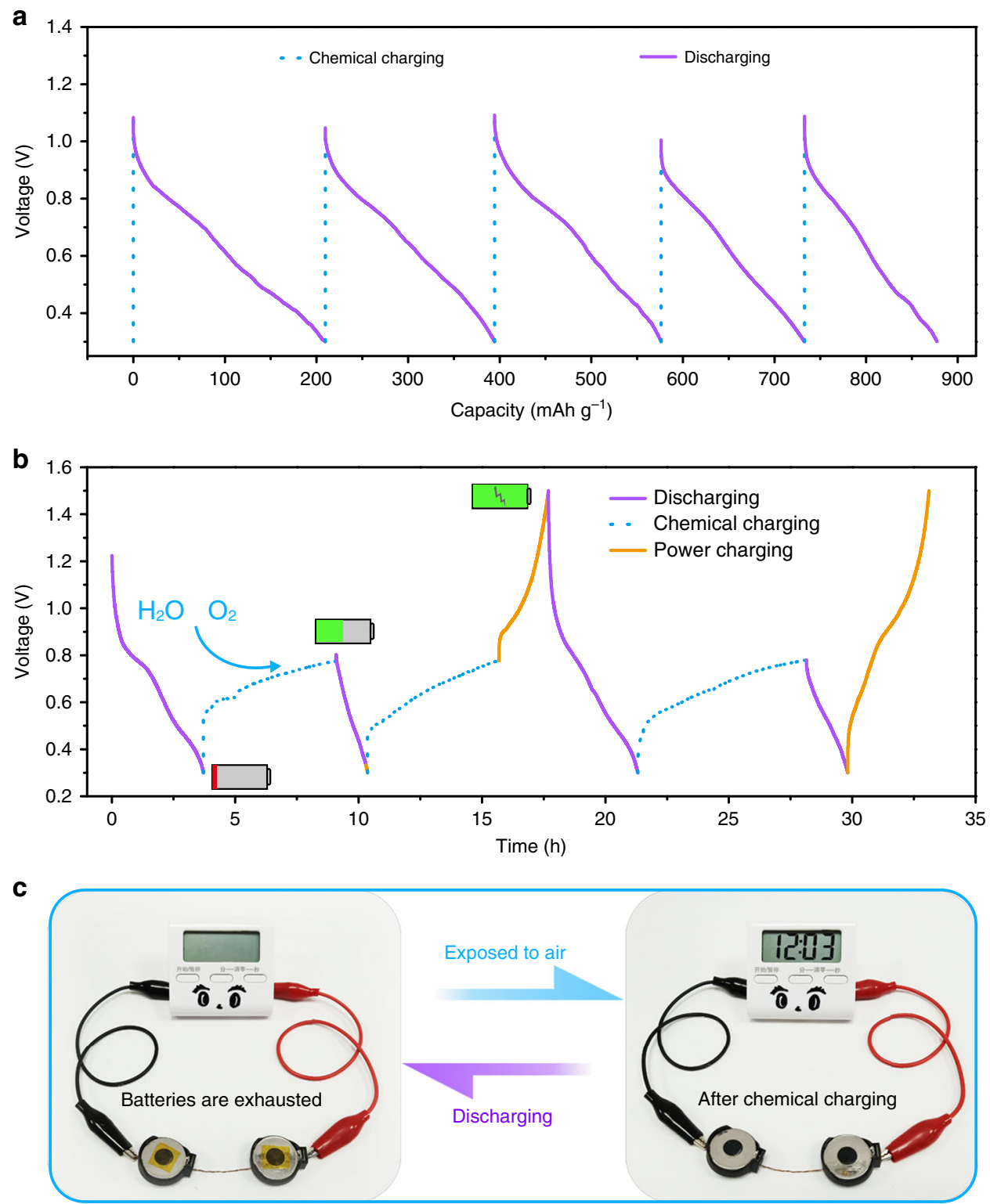

Fig. 5 In situ chemical charging behavior of the "open" ZIBs at different modes. a Repeated chemical charging/galvanostatic discharging cycles of the ZIBs. b Charging/discharging behavior of the ZIBs at chemical or/and galvanostatic charging hybrid modes. $\mathbf{c} A$ timer powered by two self-charging ZIBs in series at (left) exhausted and (right) chemically charged states.

even after several chemical-recharging/galvanostatic-recharging cycling (Fig. 4f). It could be ascribed to the structural stress generated from continuous extraction/insertion of $\mathrm{Zn}^{2+}$ ions, during the repeated chemical charging/galvanostatic discharging cycles $^{25,34}$.

According to the redox reaction mechanism, $\mathrm{O}_{2}$ and $\mathrm{H}_{2} \mathrm{O}$ are essential in the chemical charging process. Considering that water-based electrolyte was utilized in aqueous ZIBs and the $\mathrm{Zn}$ anode was stable in ambient air ${ }^{58-60}$, we designed "open" cointype aqueous ZIBs, where the cathode caps were predrilled with holes to import $\mathrm{O}_{2}$ into electrolyte and then reacted with $\mathrm{CaZn}_{3.6} \mathrm{VO}$ to realize the chemical charging process in situ. In such chemically self-charging ZIBs, the CaVO cathode simultaneously serves as an electrode for energy conversion and storage. After the batteries were fully discharged, the gas diffusion window was opened to ensure that $\mathrm{O}_{2}$ could continuously diffuse into electrolyte and react with $\mathrm{CaZn}_{3.6} \mathrm{VO}$ cathode. These "open" coin-type ZIBs still exhibit superior self-rechargeability, as reflected by the repeated chemical charging/galvanostatic discharging cycles (Fig. 5a). Furthermore, the chemical charging/ galvanostatic discharging process is also reversible. In addition, such chemically self-charging ZIBs can work at multiple charge/ discharge modes. When they are chemically charged, the OCV slowly reaches $\sim 0.77 \mathrm{~V}$ (Fig. 5b, Supplementary Fig. 28). After the batteries are exhausted, they can be chemically recharged again. Impressively, when the external power supply is available, the batteries can be galvanostatically recharged from self-charged state $(0.77 \mathrm{~V})$ to the fully charged state $(1.5 \mathrm{~V})$. Furthermore, it is worth mentioning that the operation of chemical charging process has almost no effect on the subsequent galvanostatic charging/discharging process. Similar GCD behavior is observed after several chemical charging cycles (Fig. 5b, Supplementary Fig. 29), indicating the excellent reusability of these chemically self-charging ZIBs. To demonstrate the feasibility of the resultant chemically self-charging ZIBs via a simple visual cue, two "open" coin-type batteries were connected in series to power a timer. 
After the batteries were exhausted and then exposed to the air, they could be chemically recharged to light up the liquid crystal display from the timer (Fig. 5c), suggesting their availability as chemically self-charging energy storage devices.

\section{Discussion}

The recharging and reuse of commercial batteries is often limited in the harsh environment or remote area, where electrical grid is unavailable. Therefore, self-charging power systems that integrate energy harvesting devices and batteries together must be considered. The rational design of self-charging power systems mainly depends on the fabrication of innovative electrodes and the construction of simplified device configurations. In our case, the favorable nanoribbon morphology, open framework and expanded interlayer spacing endow $\mathrm{CaVO}$ with the fast kinetics of $\mathrm{Zn}^{2+}$ ion insertion/extraction in the layered structure. As a result, $\mathrm{Zn} / \mathrm{CaVO}$ batteries exhibit a high initial discharge capacity $\left(300 \mathrm{mAh} \mathrm{g}^{-1}\right.$ at $\left.0.1 \mathrm{~A} \mathrm{~g}^{-1}\right)$, excellent rate performance $(62 \mathrm{mAh}$ $\mathrm{g}^{-1}$ at $30 \mathrm{~A} \mathrm{~g}^{-1}$ ) and outstanding cycling stability ( $100 \%$ capacity retention after 10,000 cycles). Owing to the redox potential difference between the fully discharged product $\mathrm{CaZn}_{3.6} \mathrm{VO}$ and $\mathrm{O}_{2}$, the redox reaction between them will occur, where $\mathrm{CaZn}_{3.6} \mathrm{VO}$ releases electrons to be oxidized and $\mathrm{O}_{2}$ accepts these electrons to be reduced simultaneously. Meanwhile, the $\mathrm{Zn}^{2+}$ ions are extracted from $\mathrm{CaZn}_{3.6} \mathrm{VO}$ to balance the charge. As a result, the oxidation of vanadium and extraction of the $\mathrm{Zn}^{2+}$ ions take place in $\mathrm{CaZn}_{3.6} \mathrm{VO}$ during above redox process at ambient condition. Clearly, the fully discharged product $\mathrm{CaZn}_{3.6} \mathrm{VO}$ recovers to its charged states in such redox process instead of external power. Therefore, $\mathrm{Zn} / \mathrm{CaZn}_{3.6-\mathrm{x}} \mathrm{VO}$ system can harvest chemical energy from the ambient environment and convert it to electrical energy stored in batteries through the chemical charging process. They can be self-charged to $\sim 1.05 \mathrm{~V}$ without any external power supply and deliver a considerable discharge capacity of $\sim 239 \mathrm{mAh} \mathrm{g}^{-1}$. Furthermore, the chemical charging/galvanostatic discharging process is also reversible in such open battery design. More importantly, chemically self-charging ZIBs are compatible with different chemical or/and galvanostatic charging hybrid modes. Chemically self-charging ability ensures that $\mathrm{Zn} / \mathrm{CaVO}$ batteries are available at various conditions. It is different from the conventional ZIBs and zinc-air batteries, which are only charged by external power supply. In the case of rechargeable zinc-air battery ${ }^{61}, \mathrm{O}_{2}$ is an oxidant and reduced to $\mathrm{OH}^{-}$ions via a reduction reaction at the air electrode during the discharge process. The generated $\mathrm{OH}^{-}$ions then migrate to the zinc electrode, forming insoluble zinc oxide $(\mathrm{ZnO})$ at supersaturated $\mathrm{Zn}$ $(\mathrm{OH})_{2-4}$ concentrations. In its charge process, the $\mathrm{OH}^{-}$ions are oxidized to generate $\mathrm{O}_{2}$, which is driven by external power supply. However, in our case, during the discharge process, $\mathrm{Zn}^{2+}$ ions insert into the $\mathrm{CaVO}$, which is a characteristic behavior. In this process, $\mathrm{O}_{2}$ does not participate in the reaction. During the self-charging process, the discharge product $\mathrm{CaZn}_{3.6} \mathrm{VO}$ will be oxidized by $\mathrm{O}_{2}$ due to the difference in redox potential between $\mathrm{O}_{2}$ and $\mathrm{CaZn}_{3.6} \mathrm{VO}$, replacing the electric energy to make the oxidization of discharged product and realizing the self-charging. However, during the chemical charging process, the $\mathrm{Zn}^{2+}$ ions will not be redeposited on the $\mathrm{Zn}$ anode and the formation of byproduct $\mathrm{Zn}_{\mathrm{x}+\mathrm{y}}\left(\mathrm{CF}_{3} \mathrm{SO}_{3}\right)_{2 \mathrm{y}}(\mathrm{OH})_{2 \mathrm{x}}$ will consume $\mathrm{Zn}^{2+}$ ions from the anode irreversibly, limiting the long-term chemical charging/galvanostatic discharging cycling. Significantly, the $\mathrm{Zn}_{\mathrm{x}+\mathrm{y}}\left(\mathrm{CF}_{3} \mathrm{SO}_{3}\right)_{2 \mathrm{y}}(\mathrm{OH})_{2 \mathrm{x}}$ can be decomposed by a electrochemical charging process and $\mathrm{Zn}^{2+}$ ions could be also redeposited on the $\mathrm{Zn}$ anode. This work paves the way for the potential application of ZIBs in self-charging systems, and the chemical charging strategy provides a promising research direction for the selfpowered systems.

\section{Methods}

Materials. Ammonium metavanadate $\left(\mathrm{NH}_{4} \mathrm{VO}_{3}, 99 \%\right)$ and $\mathrm{N}$-methyl-2pyrrolidone (NMP, 99.5\%) were purchased from Aladdin. Sodium dodecyl sulfate (SDS, 99\%), and polyvinylidene fluoride (PVDF) were purchased from Sinopharm Chemical Reagent Co., Ltd. Single-walled carbon nanotubes (SWCNTs, P3) were purchased from Carbon Solutions Inc. Zn foil (99.9\%) was purchased from Alfa Aesar. Glass fiber (Grade GF/A) was from Whatman. $\mathrm{Zn}\left(\mathrm{CF}_{3} \mathrm{SO}_{3}\right)_{2}, 97.5 \%$ was from J\&K Scientific Ltd. The prepared electrolyte was purified before using.

Preparation of CaVO nanoribbons. CaVO nanoribbons were fabricated by a simple hydrothermal method. A total of $117 \mathrm{mg}$ of $\mathrm{NH}_{4} \mathrm{VO}_{3}$ was added into $30 \mathrm{~mL}$ deionized water and stirred at $80^{\circ} \mathrm{C}$ for $20 \mathrm{~min}$ to obtain a clear yellowish solution. Meanwhile, $666 \mathrm{mg}$ of $\mathrm{CaCl}_{2}$ and $100 \mathrm{mg}$ SDS were dissolved in another $30 \mathrm{~mL}$ deionized water, and stirred at $60{ }^{\circ} \mathrm{C}$ for $10 \mathrm{~min}$ to achieve a transparent solution. Subsequently, the $\mathrm{CaCl}_{2}$ /SDS solution was added into $\mathrm{NH}_{4} \mathrm{VO}_{3}$ solution under stirring. Finally, the above mixture solution was transferred into a $100 \mathrm{~mL}$ Teflon lined autoclave and heated at $160^{\circ} \mathrm{C}$ for $10 \mathrm{~h}$. After cooling to room temperature, the brownish-red precipitates were washed with deionized water and freeze-dried.

Electrochemical measurement. Electrochemical performance of $\mathrm{CaVO}$ nanoribbons was measured in CR2032 coin cells. The cathode was prepared by mixing the CaVO nanoribbons, SWCNTs, and PVDF in a weight ratio of 7:2:1 by NMP. Then, the slurry was coated on stainless-steel meshes and dried at $60^{\circ} \mathrm{C}$ for $12 \mathrm{~h}$ under vacuum. The mass loading of CaVO in the cathode is $\sim 1 \mathrm{mg} \mathrm{cm}^{-2}$. Commercial glass fiber and zinc foil with a thickness of $30 \mu \mathrm{m}$ were employed as the separator and anode, respectively. Aqueous $4 \mathrm{M} \mathrm{Zn}\left(\mathrm{CF}_{3} \mathrm{SO}_{3}\right)_{2}$ solution was used as electrolyte since the high-concentration electrolyte would not only alter the solvation and transporting behaviors of cations/anions to enhance stability and kinetics, but also reduce the water activity and water-induced side reactions ${ }^{48,62-64}$ They were assembled into CR2032 coin cells by a traditional method. The GCD tests were performed on a battery test system (LAND CT2001A) with a voltage window of $0.3-1.5 \mathrm{~V}$. CV were measured using an electrochemical workstation $(\mathrm{CHI} 60 \mathrm{E})$ in a voltage window from 0.3 to $1.5 \mathrm{~V}$.

To understand the mechanism of redox reaction between $\mathrm{CaZn}_{3.6} \mathrm{VO}$ and $\mathrm{O}_{2}$, the $\mathrm{Zn} / \mathrm{CaVO}$ batteries were discharged to $0.3 \mathrm{~V}$ at a current density of $0.1 \mathrm{~A} \mathrm{~g}^{-1}$. Subsequently, the fully discharged cathodes $\left(\mathrm{CaZn}_{3.6} \mathrm{VO}\right)$ were washed by deionized water and then immersed in $4 \mathrm{M} \mathrm{Zn}\left(\mathrm{CF}_{3} \mathrm{SO}_{3}\right)_{2}$ solution or water for different times to react with the dissolved oxygen. After that, the treated $\mathrm{CaZn}_{3.6-\mathrm{x}} \mathrm{VO}$ cathodes were assembled into coin cells again for the electrochemical performance measurement. In the in situ chemical charging process, the cathode cap was predrilled with a hole to import oxygen. The cell was first sealed with a Kapton membrane, which was subsequently wiped off to enable $\mathrm{O}_{2}$ to pass through the hole. Furthermore, to avoid the excessive volatilization of water from the electrolyte, the chemical charging process was carried out under a high humidity condition $(>60 \%)$. After self-charging, the cell was sealed again. The specific capacities were calculated based on the mass of the active material $\mathrm{CaVO}$ of cathodes.

Characterization. The morphologies of $\mathrm{CaVO}$ nanoribbons and cathodes were characterized via field-emission scanning electron microscopy (SEM, JEOL JSM7500F, $5 \mathrm{kV}$ and Phenom XL, $15 \mathrm{kV}$ ). The SEM-energy dispersive spectroscopy (EDS) of the samples are collected with Phenom XL at an acceleration voltage of $15 \mathrm{kV}$. The microstructure was characterized by TEM (FEI Talos F200X and FEI Talos F200X G2) equipped with EDS mapping at an acceleration voltage of $200 \mathrm{kV}$. The crystalline structure of samples was determined by XRD (Rigaku SmartLab) with $\mathrm{Cu} \mathrm{Ka}$ radiation $(\lambda=0.15405 \mathrm{~nm})$. TGA (Netzsch STA $449 \mathrm{~F} 3$ Jupiter analyzer) was carried out in an Ar flow from room temperature to $600^{\circ} \mathrm{C}$ at a heating rate of $10^{\circ} \mathrm{C} \mathrm{min}-1$. In situ XRD experiments were performed using home-made cells that were designed with Be window for X-ray penetration. XPS (PerkinElmer PHI 1600 ESCA) was used to characterize the composition and surface oxidation state of the electrodes. V K-edge XANES spectra were collected at the beamline 14W1 in Shanghai Synchrotron Radiation Facility. The solid state ${ }^{1} \mathrm{H}$ nuclear magnetic resonance ( ${ }^{1} \mathrm{H}$ NMR) was taken from a $400 \mathrm{MHz}$ superconducting NMR spectrometer (AVANCE ||| 400).

\section{Data availability}

The authors declare that all the relevant data are available within the paper and its Supplementary Information file or from the corresponding author upon reasonable request.

Received: 14 August 2019; Accepted: 7 April 2020; Published online: 04 May 2020 


\section{References}

1. Dunn, B., Kamath, H. \& Tarascon, J.-M. Electrical energy storage for the grid: a battery of choices. Science 334, 928-935 (2011).

2. Xu, C., Li, B., Du, H. \& Kang, F. Energetic zinc ion chemistry: the rechargeable zinc ion battery. Angew. Chem. Int. Ed. 51, 933-935 (2012).

3. Wu, X. \& Ji, X. Aqueous batteries get energetic. Nat. Chem. 11, 680-681 (2019).

4. Huang, J. et al. Polyaniline-intercalated manganese dioxide nanolayers as a high-performance cathode material for an aqueous zinc-ion battery. Nat. Commun. 9, 2906 (2018).

5. Luo, B., Ye, D. \& Wang, L. Recent progress on integrated energy conversion and storage systems. Adv. Sci. 4, 1700104 (2017).

6. Schmidt, D., Hager, M. D. \& Schubert, U. S. Photo-rechargeable electric energy storage systems. Adv. Energy Mater. 6, 1500369 (2016).

7. Chen, T. et al. An integrated "energy wire" for both photoelectric conversion and energy storage. Angew. Chem. Int. Ed. 51, 11977-11980 (2012).

8. Paolella, A. et al. Light-assisted delithiation of lithium iron phosphate nanocrystals towards photo-rechargeable lithium ion batteries. Nat. Commun. 8, 14643 (2017).

9. Li, Q., Li, N., Liu, Y., Wang, Y. \& Zhou, H. High-safety and low-cost photoassisted chargeable aqueous sodium-ion batteries with $90 \%$ input electric energy savings. Adv. Energy Mater. 6, 1600632 (2016).

10. Xu, J., Chen, Y. \& Dai, L. Efficiently photo-charging lithium-ion battery by perovskite solar cell. Nat. Commun. 6, 8103 (2015).

11. Yu, M., Ren, X., Ma, L. \& Wu, Y. Integrating a redox-coupled dye-sensitized photoelectrode into a lithium-oxygen battery for photoassisted charging. Nat. Commun. 5, 5111 (2014).

12. Kim, Y.-S. et al. Highly porous piezoelectric PVDF membrane as effective lithium ion transfer channels for enhanced self-charging power cell. Nano Energy 14, 77-86 (2015).

13. Xue, X., Wang, S., Guo, W., Zhang, Y. \& Wang, Z. L. Hybridizing energy conversion and storage in a mechanical-to-electrochemical process for selfcharging power cell. Nano Lett. 12, 5048-5054 (2012).

14. Wang, Z. et al. Integrating a triboelectric nanogenerator and a zinc-ion battery on a designed flexible 3D spacer fabric. Small Methods 2, 1800150 (2018).

15. $\mathrm{Pu}, \mathrm{X}$. et al. A self-charging power unit by integration of a textile triboelectric nanogenerator and a flexible lithium-ion battery for wearable electronics. Adv. Mater. 27, 2472-2478 (2015).

16. Yang, Y. et al. Charging-free electrochemical system for harvesting low-grade thermal energy. Proc. Natl Acad. Sci. USA 111, 17011-17016 (2014).

17. Lee, S. W. et al. An electrochemical system for efficiently harvesting low-grade heat energy. Nat. Commun. 5, 3942 (2014)

18. Zhang, F., Liu, J., Yang, W. \& Logan, B. E. A thermally regenerative ammoniabased battery for efficient harvesting of low-grade thermal energy as electrical power. Energy Environ. Sci. 8, 343-349 (2015).

19. Thimmappa, R. et al. Chemically chargeable photo battery. J. Phys. Chem. C 119, 14010-14016 (2015).

20. Wang, J. et al. A bi-functional device for self-powered electrochromic window and self-rechargeable transparent battery applications. Nat. Commun. 5, 4921 (2014).

21. Pankratov, D., Falkman, P., Blum, Z. \& Shleev, S. A hybrid electric power device for simultaneous generation and storage of electric energy. Energy Environ. Sci. 7, 989-993 (2014).

22. $\mathrm{Wu}, \mathrm{X}$. et al. Reverse dual-ion battery via a $\mathrm{ZnCl}_{2}$ water-in-salt electrolyte. $J$. Am. Chem. Soc. 141, 6338-6344 (2019).

23. $\mathrm{Ma}, \mathrm{L}$. et al. A usage scenario independent "air chargeable" flexible zinc ion energy storage device. Adv. Energy Mater. 9, 1900509 (2019).

24. Luo, Z., Liu, C., Fan, S. \& Liu, E. A universal in situ strategy for charging supercapacitors. J. Mater. Chem. A 7, 15131-15136 (2019).

25. Kundu, D., Adams, B. D., Duffort, V., Vajargah, S. H. \& Nazar, L. F. A highcapacity and long-life aqueous rechargeable zinc battery using a metal oxide intercalation cathode. Nat. Energy 1, 16119 (2016).

26. Wan, F. et al. Aqueous rechargeable zinc/sodium vanadate batteries with enhanced performance from simultaneous insertion of dual carriers. Nat. Commun. 9, 1656 (2018)

27. Yan, $\mathrm{M}$. et al. Water-lubricated intercalation in $\mathrm{V}_{2} \mathrm{O}_{5} \cdot \mathrm{nH}_{2} \mathrm{O}$ for high-capacity and high-rate aqueous rechargeable zinc batteries. Adv. Mater. 30, 1703725 (2018).

28. Chao, D. et al. A high-rate and stable quasi-solid-state zinc-ion battery with novel 2D layered zinc orthovanadate array. Adv. Mater. 30, 1803181 (2018).

29. Yang, Y. et al. $\mathrm{Li}^{+}$intercalated $\mathrm{V}_{2} \mathrm{O}_{5} \cdot \mathrm{nH}_{2} \mathrm{O}$ with enlarged layer spacing and fast ion diffusion as an aqueous zinc-ion battery cathode. Energy Environ. Sci. 11, 3157-3162 (2018).

30. Wan, F. \& Niu, Z. Design strategies for vanadium-based aqueous zinc-ion batteries. Angew. Chem. Int. Ed. 58, 16358-16367 (2019).

31. Kong, L., Shao, M., Xie, Q., Liu, J. \& Qian, Y. Hydrothermal growth of single-crystal $\mathrm{CaV}_{6} \mathrm{O}_{16} \cdot 3 \mathrm{H}_{2} \mathrm{O}$ nanoribbons. J. Cryst. Growth 260, 435-439 (2004).
32. Zhang, $\mathrm{X}$. et al. Ultralong metahewettite $\mathrm{CaV}_{6} \mathrm{O}_{16} \cdot 3 \mathrm{H}_{2} \mathrm{O}$ nanoribbons as novel host materials for lithium storage: towards high-rate and excellent long-term cyclability. Nano Energy 22, 38-47 (2016).

33. Liu, $X$. et al. Calcium vanadate sub-microfibers as highly reversible host cathode material for aqueous zinc-ion batteries. Chem. Commun. 55, 2265-2268 (2019).

34. Xia, C., Guo, J., Li, P., Zhang, X. \& Alshareef, H. N. Highly stable aqueous zinc-ion storage using a layered calcium vanadium oxide bronze cathode. Angew. Chem. Int. Ed. 57, 3943-3948 (2018).

35. Ma, L. et al. Initiating a mild aqueous electrolyte $\mathrm{Co}_{3} \mathrm{O}_{4} / \mathrm{Zn}$ battery with $2.2 \mathrm{~V}$ high voltage and 5000-cycle lifespan by a Co(iii) rich-electrode. Energy Environ. Sci. 11, 2521-2530 (2018).

36. Zeng, Y. et al. Oxygen-vacancy and surface modulation of ultrathin nickel cobaltite nanosheets as a high-energy cathode for advanced $\mathrm{Zn}$-ion batteries. Adv. Mater. 30, 1802396 (2018).

37. Zhu, K., Wu, T. \& Huang, K. $\mathrm{NaCa}_{0.6} \mathrm{~V}_{6} \mathrm{O}_{16} \cdot 3 \mathrm{H}_{2} \mathrm{O}$ as an ultra-stable cathode for $\mathrm{Zn}$-ion batteries: the roles of pre-inserted dual-cations and structural water in $\mathrm{V}_{3} \mathrm{O}_{8}$ layer. Adv. Energy Mater. 9, 1901968 (2019).

38. $\mathrm{Hu}, \mathrm{P}$. et al. Highly durable $\mathrm{Na}_{2} \mathrm{~V}_{6} \mathrm{O}_{16} \cdot 1.63 \mathrm{H}_{2} \mathrm{O}$ nanowire cathode for aqueous zinc-ion battery. Nano Lett. 18, 1758-1763 (2018).

39. Ding, J. et al. Ultrafast $\mathrm{Zn}^{2+}$ intercalation and deintercalation in vanadium dioxide. Adv. Mater. 30, 1800762 (2018).

40. Ming, F. et al. Layered $\mathrm{Mg}_{\mathrm{x}} \mathrm{V}_{2} \mathrm{O}_{5} \cdot \mathrm{nH}_{2} \mathrm{O}$ as cathode material for highperformance aqueous zinc ion batteries. ACS Energy Lett. 3, 2602-2609 (2018).

41. Xia, C. et al. Rechargeable aqueous zinc-ion battery based on porous framework zinc pyrovanadate intercalation cathode. Adv. Mater. 30, 1705580 (2018).

42. Chen, L. et al. Ultrastable and high-performance $\mathrm{Zn} / \mathrm{VO}_{2}$ battery based on a reversible single-phase reaction. Chem. Mater. 31, 699-706 (2019).

43. Soundharrajan, V. et al. $\mathrm{Na}_{2} \mathrm{~V}_{6} \mathrm{O}_{16} \cdot 3 \mathrm{H}_{2} \mathrm{O}$ barnesite nanorod: An open door to display a stable and high energy for aqueous rechargeable $\mathrm{Zn}$-ion batteries as cathodes. Nano Lett. 18, 2402-2410 (2018).

44. Wang, L., Huang, K.-W., Chen, J. \& Zheng, J. Ultralong cycle stability of aqueous zinc-ion batteries with zinc vanadium oxide cathodes. Sci. Adv. 5 , eaax4279 (2019).

45. Guo, X. et al. Mechanistic insights of $\mathrm{Zn}^{2+}$ storage in sodium vanadates. $A d v$. Energy Mater. 8, 1801819 (2018).

46. Tang, B. et al. Potassium vanadates with stable structure and fast ion diffusion channel as cathode for rechargeable aqueous zinc-ion batteries. Nano Energy 51, 579-587 (2018).

47. Shin, J., Choi, D. S., Lee, H. J., Jung, Y. \& Choi, J. W. Hydrated intercalation for high-performance aqueous zinc ion batteries. Adv. Energy Mater. 9, 1900083 (2019)

48. Wang, F. et al. A rechargeable aqueous $\mathrm{Zn}^{2+}$-battery with high power density and a long cycle-life. Energy Environ. Sci. 11, 3168-3175 (2018).

49. Alfaruqi, M. H. et al. Electrochemical zinc intercalation in lithium vanadium oxide: a high-capacity zinc-ion battery cathode. Chem. Mater. 29, 1684-1694 (2017).

50. Wan, F. et al. Reversible oxygen redox chemistry in aqueous zinc-ion batteries Angew. Chem. Int. Ed. 58, 7062-7067 (2019).

51. Gao, J., Shi, S.-Q. \& Li, H. Brief overview of electrochemical potential in lithium ion batteries. Chin. Phys. B 25, 018210 (2016).

52. Li, H., McRae, L., Firby, C. J. \& Elezzabi, A. Y. Rechargeable aqueous electrochromic batteries utilizing Ti-substituted tungsten molybdenum oxide based $\mathrm{Zn}^{2+}$ ion intercalation cathodes. Adv. Mater. 31, 1807065 (2019).

53. Li, X. et al. Bringing hetero-polyacid-based underwater adhesive as printable cathode coating for self-powered electrochromic aqueous batteries. Adv. Funct. Mater. 28, 1800599 (2018).

54. Wang, X. et al. Large-area reduced graphene oxide composite films for flexible asymmetric sandwich and microsized supercapacitors. Adv. Funct. Mater. 28, 1707247 (2018).

55. Cao, X. et al. Ambient fabrication of large-area graphene films via a synchronous reduction and assembly strategy. Adv. Mater. 25, 2957-2962 (2013).

56. Oberholzer, P., Tervoort, E., Bouzid, A., Pasquarello, A. \& Kundu, D. Oxide versus nonoxide cathode materials for aqueous $\mathrm{Zn}$ batteries: an insight into the charge storage mechanism and consequences thereof. ACS Appl. Mater. Interfaces 11, 674-682 (2019).

57. Liu, Y., Li, Q., Ma, K., Yang, G. \& Wang, C. Graphene oxide wrapped $\mathrm{CuV}_{2} \mathrm{O}_{6}$ nanobelts as high-capacity and long-life cathode materials of aqueous zinc-ion batteries. ACS Nano 13, 12081-12089 (2019).

58. Song, M., Tan, H., Chao, D. \& Fan, H. J. Recent advances in Zn-ion batteries. Adv. Funct. Mater. 28, 1802564 (2018).

59. Huang, J. et al. Recent progress of rechargeable batteries using mild aqueous electrolytes. Small Methods 3, 1800272 (2019)

60. Yu, P. et al. Flexible $\mathrm{Zn}$-ion batteries: recent progresses and challenges. Small 15, 1804760 (2019).

61. Fu, J. et al. Electrically rechargeable zinc-air batteries: progress, challenges, and perspectives. Adv. Mater. 29, 1604685 (2017). 
62. Zhang, N. et al. Cation-deficient spinel $\mathrm{ZnMn}_{2} \mathrm{O}_{4}$ cathode in $\mathrm{Zn}\left(\mathrm{CF}_{3} \mathrm{SO}_{3}\right)_{2}$ electrolyte for rechargeable aqueous $\mathrm{Zn}$-ion battery. J. Am. Chem. Soc. 138, 12894-12901 (2016).

63. Suo, L. M. et al. "Water-in-salt" electrolyte enables high-voltage aqueous lithium-ion chemistries. Science 350, 938-943 (2015).

64. Wang, F. et al. Highly reversible zinc metal anode for aqueous batteries. Nat. Mater. 17, 543-549 (2018).

\section{Acknowledgements}

This work was supported by National Natural Science Foundation of China (51822205, 21573116, and 21875121), Ministry of Science and Technology of China

(2017YFA0206701), Ministry of Education of China (B12015), and the Young Thousand Talents Program and Natural Science Foundation of Tianjin (18JCJQJC46300). The authors thank Professor Jun Luo (Center for Electron Microscopy, Institute for New Energy Materials and Low-Carbon Technologies, Tianjin University of Technology) for TEM measurements and Professor Li Song (National Synchrotron Radiation Laboratory, CAS Center for Excellence in Nanoscience University of Science and Technology of China) for help in XANES characterizations. Dedicated to the 100th anniversary of Nankai University.

\section{Author contributions}

J.C., Z.N., and Y.Z. conceived this idea, and designed the experiments. J.C. and Z.N. directed the project. Y.Z. performed the experiments. F.W., S.W., and S.H. carried out the electrochemical measurements, and analyzed the data. J.C., Z.N., and Y.Z. wrote the paper. All authors discussed the results and commented on the manuscript.

\section{Competing interests}

The authors declare no competing interests.

\section{Additional information}

Supplementary information is available for this paper at https://doi.org/10.1038/s41467020-16039-5.

Correspondence and requests for materials should be addressed to Z.N.

Peer review information Nature Communications thanks the anonymous reviewer(s) for their contribution to the peer review of this work.

Reprints and permission information is available at http://www.nature.com/reprints

Publisher's note Springer Nature remains neutral with regard to jurisdictional claims in published maps and institutional affiliations.

(c) (i) Open Access This article is licensed under a Creative Commons Attribution 4.0 International License, which permits use, sharing, adaptation, distribution and reproduction in any medium or format, as long as you give appropriate credit to the original author(s) and the source, provide a link to the Creative Commons license, and indicate if changes were made. The images or other third party material in this article are included in the article's Creative Commons license, unless indicated otherwise in a credit line to the material. If material is not included in the article's Creative Commons license and your intended use is not permitted by statutory regulation or exceeds the permitted use, you will need to obtain permission directly from the copyright holder. To view a copy of this license, visit http://creativecommons.org/ licenses/by/4.0/.

(C) The Author(s) 2020 